justified to prevent future vascular problems, although sometimes it may be indicated for social reasons. Even in obstructive sleep apnoea the lack of properly funded regional sleep centres and the fact that continuous positive airway pressure is not prescribable in the NHS or funded under most private insurance schemes present considerable problems that need to be urgently considered. Teasing out the interrelations among snoring, obstructive sleep apnoea, vascular complications, and predisposing factors such as obesity also awaits proper funding.

Consultant Physician,

United Medical and Dental Schools,

Guy's Hospital,

London SE1 9RT

1 American Sleep Disorders Association. International classification of sleep disorders: diagnostic and coding manual. Rochester, Minnesota: American Sleep Disorders Association, 1990.

Stroling JR, Crosby JH. Relation between systemic hypertension and sleep hypoxaemia or snoring: analysis in 748 men drawn from general practice. $B M \mathcal{F}$ 1990;300:75-8.

3 Norton PG, Dunn EV. Snoring as a risk factor for disease: an epidemiological survey. $B M \mathcal{J}$ 1985;291:630-2.

4 Corbo GM, Fuciarelli F, Foresi A, De Benedetto F. Snoring in children: association with respiratory symptoms and passive smoking. BMF 1989;299:1491-4
Koskenvuo M, Kapiro J, Partinen M, Langinvainio H, Sarna S, Heikkila K. Snoring as a risk factor for hypertension and angina pectoris. Lancet 1985;ii:893-6.

6 Partinen M, Palomaki H. Snoring and cerebral infarction. Lancet 1985;ii: 1325

Koskenvuo M, Kapiro J, Telakivi K, Partinen M, Heikkila K, Sarna S. Snoring as a risk factor for ischaemic heart disease and stroke in men. BMF 1987;294:16-9.

Bloom JW, Kaltentorn WT, Quan SF. Risk factors in a general population for snoring. Importance of cigarette smoking and obesity. Chest 1988:93:678-83.

Schmidt Nowara WW Coulas DB, Wiggins C, Skipper BE Same JM. Snoring in a HispanicAmerican popution. Risk fact wiggin $C$, Skipper BE, San

10 Hoffstein V, Rubinstein I, Mateika S, Slutsky AS. Determinants of blood pressure in snorers. Lancet 1988;ii:992-4.

11 Welin L, Svardsudd K, Wilhelmsen L, Larsson B, Tibblin G. Analysis of risk factors for stroke in a cohort of men born in 1913. N Engl f Med 1987;317:521-6.

2 Katz I, Stradling J, Slutsky AS, Zamel N, Hoffstein V. Do patients with sleep apnea have a short, fat neck? Am Rev Respir Dis 1989;139:622.

13 Waller PC, Bhopal RS. Is snoring a cause of vascular disease? An epidemiological review. Lance 1989;: 143-6.

14 Rodenstein DO, Dooms G, Thomas Y, et al. Pharyngeal shape and dimensions in healthy subjects, snorers, and patients with obstructive sleep apnoea. Thorax 1990;45:722-7.

15 Lavie P. Incidence of sleep apnea in a presumably healthy working population. Sleep 1983;6:312-8. 16 Gislason T, Almqvist M, Eriksson G, Taube A, Boman G. Prevalence of sleep apnea syndrome among Swedish men-an epidemiological study. I Clin Epidemiol 1988;41:571-6.

17 Gonzalez-Rothi RJ, Foresman GE, Block AJ. Do patients with sleep apnea die in their sleep? Chest 1988;94:531-8.

$18 \mathrm{He} \mathrm{J}$, Kryger MH, Zorick FJ, Conway W, Roth T. Mortality and apnea index in obstructive sleep apnea (experience in 385 male patients). Chest 1988;94:9-14.

19 Partinen $M$, Jamieson A, Guilleminault C. Long-term outcome for obstructive sleep apnea Partinen M, Jamieson A, Guilleminault C. Long-te:
syndrome patients (mortality). Chest 1988;94:1200-4.

20 Hing J, Whitford EG, Parsons RW, Hillman DR. Association of sleep apnoea with myocardia infarction in men. Lancet 1990;336:261-4.

21 Rees PJ, Clark TJH. Paroxysmal nocturnal dyspnoea and periodic ventilation. Lancet 1979;ii $1315-7$.

\title{
Breast cancer genes
}

\author{
Progress, but still a long way to go
}

Researchers have recently made important advances in understanding familial breast cancer with the discovery of two genetic loci that are associated with inheritance of the disease. ${ }^{1-3}$ Dr Mary-Claire King and her colleagues at the University of California have identified in a set of families a locus in the long arm of chromosome 17 that is linked to susceptibility to onset of breast cancer at a young age.' Linkage to this locus has also been found in three extensive families with a combination of breast and ovarian cancer ( $J$ Feunteun, G Lenoir, unpublished observations). It lies in a region where several possible candidates for genes predisposing towards breast cancer are present, although whether one of these is the breast cancer susceptibility gene is still unknown.

Inherited mutations have also been found on the short arm of chromosome 17 in a particular region of the p53 gene ${ }^{23}$ (which has been implicated in the progression of several tumours) in six families with the Li-Fraumeni syndrome. ${ }^{4}$ In these families, bone and soft tissue sarcomas are associated with various tumours at other sites, notably young onset breast cancer. Other tumours occurring in excess include brain tumours, adrenal cortical tumours, and leukaemias. Although these results excite researchers, it will be some time before they can be used in the counselling of families with a history of breast cancer; and even then they will not be useful in all such families.

Familial breast cancer poses several clinical problems. The first is recognition. Breast cancer is common, and cases will occur together in families by chance. One may estimate whether or not a given family may carry a genetic predisposition from the extent of the family history, the ages at which family members have developed cancer, the occurrence of bilateral cases, and whether the types of cancer fall into a recognised pattern such as combined breast and ovarian cancers or the unusual cancers of Li-Fraumeni syndrome. After it has been decided that a family may carry a genetic predisposition the second problem is to estimate the risk to family members. In such families, predisposition towards cancer is generally thought to be dominantly inherited, ${ }^{5}$ so that, on average, only half the children of gene carriers will inherit the gene.

To identify gene carriers one must have either a DNA marker or a specific phenotype (for example, gene carriers for familial polyposis are distinguished by their multiple intestinal polyps). Until now no reliable marker for susceptibility to breast cancer has been available so that assigning very high or very low risks to specific family members has been difficult. The third problem, having estimated the risk, is to decide what should be done about it. Screening is controversial. Although no evidence exists for benefit in younger women generally, screening has not been tested in high risk families, and many clinicians recommend it. Prophylactic mastectomy is seldom chosen, at least in Britain, perhaps because confidently identifying someone at sufficiently high risk is impossible.

The new findings may help solve some of these problems, but they will highlight others. The six families with $\mathrm{Li}^{-}$ Fraumeni syndrome in which p53 mutations have been reported so far were selected for detailed study because of their extensive pedigrees. ${ }^{23}$ Such families are extremely rare. Studies may now be done to see what proportion of all young women with breast cancer, regardless of family history, carry such a mutation. (Preliminary results suggest that these will be very few.) In families carrying a p 53 mutation members at risk (and just as importantly, those not at risk) may be identified. One should not assume, however, the pattern and risk of cancers will be the same in all these families as in the spectacular examples so far reported. We should now be able to establish more precisely which cancers occur more commonly as a result of the mutation, whether different mutations predict a different spectrum of cancers, and the risk of cancer by a given age.

Once risk estimates can be made, we must also consider whether it is in their best interests for people to know that they 
have inherited a p53 mutation. Reassuring anxious family members who prove not to have the mutation will be possible, but that information cannot be gained without the risk of finding others who have. For these others, until effective screening or treatment is available, the knowledge of risk is likely to be unhelpful, producing anxiety as well as practical problems with employment and insurance.

The new results are exciting because they are the first substantial successes with the hitherto intractable problem of inherited breast cancer. The two genes recognised so far probably account for only a minority of familial breast cancers, and other genes are likely to be found. So long as an unproved and probably imperfect screening test or a prophylactic operation are all that we have to offer women at risk, however, the clinical impact of these discoveries is bound to be limited.

Familial cases make up only a small proportion of all breast cancers. In the longer term we can hope that knowledge of how the mutated genes predispose to breast cancer will lead to a better understanding of both familial and sporadic breast cancers and ultimately to more widely applicable methods of prevention and treatment.

Director,

B A J PONDER

Cancer Research Campaign Human Cancer Genetics Research Group,

Department of Pathology, University of Cambridge,

Cambridge CB2 1QP

On behalf of the Cancer Families Study Group ${ }^{\star}$

1 Hall JM, Lee MK, Newman B, et al. Linkage of early onset familial breast cancer to chromosome 17q21. Science 1990;250:1684-9.

Malkin D, Li FP, Strong LC, et al. Germline 53 mutations in a familial sundrome of breast cancer sarcomas and other neoplasms. Science 1990;250:1233-8.

Srivastava S, Zou Z. Pirollo K, Blattner W, Chang E. Germline transmission of a mutated 553 genc in a cancer-prone family with Li-Fraumeni syndrome. Nature 1990;338:737-9.

in a cancer-prone family with Li-Fraumeni syndrome. Nature $1990,338.737-9$. syndrome? Ann Intern Med 1969;71:737-51.

syndrome? Ann Intern Med 1969;71:737-51.
Newman B, Austin MA, Lee M, King M-C.

Newman B, Austin MA, Lee M, King M-C. Inheritance of human breast cancer: evidence for autosomal dominant transmission in high-risk families. Proc Natl Acad Sci USA 1988;85:3033-8.

* The Cancer Families Study Group is a national collaborative group which includes scientists and clinicians from CRC (Cambridge, Manchester, Sutton), ICRF (London, Leeds), MRC Edinburgh), and many university departments and hospitals and participants from several European centres. The group was set up some years ago to coordinate studies of familial cancer in the United Kingdom. Members are currently evaluating the new findings in breast cancer in families from the United Kingdom. For further information contact Miss Caroline Jenkinson, Imperial Cancer Research Fund, 3K Springfield House, Hyde Terrace, Leeds LS2 9LU.

\section{Through American eyes}

\section{They see the NHS from both sides}

Given the nature of the NHS reforms introduced on 1 April, it is perhaps unsurprising to find that many American doctors are keenly interested in them. After all, American health economist, Alain Enthoven, is credited with being the original architect of the reforms, and many commentators on both sides of the Atlantic maintain that the effect of the reforms will be to make British medicine more like that practised in America. It is therefore interesting to compare the views of two American doctors who have recently turned their attention to this subject.

Donald Light, who is a professor and consultant in health policy at the University of Medicine and Dentistry in New Jersey, and John Roberts, an American internist formerly at Chapel Hill, recently wrote a series of articles in the Health Service fournal and the $B M \mathcal{F}$, respectively..$^{1.9}$ In different ways they addressed broadly the same two questionsnamely, "When compared with health care in the United States, what are the strengths and weaknesses of the NHS?" and "What impact are the reforms likely to have on these strengths and weaknesses?".

Roberts explicitly and Light by implication agree that the NHS has strengths that most informed Americans admire. High on the list of strengths is primary care and, in particular, general practice; as Roberts puts it, "For an American visitor general practice represents the best of British medicine. The list system ensures that all get a doctor. Vulnerable patients ... are seen regularly, often in their homes. The referral system ensures that specialty services are not overused." ${ }^{\text {" For most }}$ Americans engaged in health care, these kinds of achievements remain distant aspirations. Between them the two authors highlight several other strengths which typically impress Americans. For example, they point out that the NHS is very good value for money (even though about one in five Americans get little or no medical care, the United States spends three times as much on health care); that the NHS spends very little on administration per capita; that, unlike their American counterparts, NHS doctors tend not to "overtreat"; and so on.

Both writers also draw attention to a number of weaknesses.
Near the top of the list, of course, are NHS waiting lists something that always surprises Americans because the : United States has no such lists. Waiting lists are closely followed by inefficiency. Light identifies examples of what he calls waste and inefficiency in the NHS, including inefficiencies due to underfunding and idle resources; wasted bed days; unnecessary bed days; underused theatre time; underuse of the general practitioner network; and high staff turnover.

Other weaknesses identified by the two writers include the poor state of the NHS's capital stock and the "paternalism" of British medicine and of British doctors in particular. While not necessarily implying that it is a weakness, Roberts also highlights the "austerity" of the NHS - a term he uses to draw attention to the fact that by comparison with their American counterparts, NHS doctors see very little of, and do very little to, their patients.

Although neither writer attempts to reach an overall 0 judgment as to the relative merits of the two systems, it is clear $N$ that both feel that the NHS has much to recommend it. of Roberts comes closest to making an overall judgment: "But this austere, inefficient [NHS] system is fair. Everyone gets a doctor free of charge, and nearly everyone stands in the same queue. British doctors claim it is a safe system: financial constraints mean that needless tests are avoided, often because the tests are simply not available nearby." Later in the same paragraph he quotes approvingly a British philosophy $\stackrel{\odot}{+}$ professor: "In the United States doctors are paid to do more; in England they are paid to do less. I feel safer in England."

So what then do Light and Roberts make of the reforms? The short answer is that both are clearly worried. Light in particular is worried by the idea of an internal market, competition between health care providers, and the admini- 8 strative bureaucracy he is convinced that this will engender. "The Conservatives have been seriously misled by advisors advocating competition, not because of any inherent weak- ? nesses of competition as a strategy, but because it works badly in health care"' and "People who think bureaucracy is bad and markets are good should take a look at the bureaucracy and regulations needed to set up a medical market."' 